Irina Matveevna Romanova ${ }^{1}$

Elena Viktorovna Noskova ${ }^{2}$

School of Economics and Management,

Far Eastern Federal University, Russia
SCIENTIFIC REVIEW ARTICLE doi:10.5937/ekonomika1503017M

Received: May 6, 2015

Accepted: June 22, 2015

\title{
INVESTIGATION OF CROSS-CULTURAL DISTINCTIONS EFFECT ON THE CONSUMERS' BEHAVIOR IN THE HIGHER EDUCATION MARKET ${ }^{3}$
}

\begin{abstract}
The article states that the investigations of the cross-cultural distinctions effect on the consumer behaviour are challenging and popular in the international scientific and business community and are of the interdisciplinary character. The objective of this investigation is to develop the methodological approach to the assessment of the cross-cultural features impact on the consumers' behaviour in the higher educational services market. The culture model disclosing the list of the cultural values, material and institutional environment characteristics, adapted to the Universities educational services market, was developed during this investigation. The method for creating the contingency matrix of the elements, forming the model of a certain country consumers' culture, and the consumers (students) behavioural features in the market of the higher educational services grouped against the $7 P$ complex (Product, Price, Promotion, People, Process, Physical evidence) has been suggested. The developed methodical approach has been approved by Chinese and Russian students. The investigation outcomes can be used to develop the measures to improve the international competitiveness of universities.
\end{abstract}

Key words: cross-culture, culture model, consumers'behaviour

JEL classification: M 390

\footnotetext{
${ }^{1}$ romanova.im@dvfu.ru

2 noskova.ev@dvfu.ru

${ }^{3}$ Acknowledgement: The authors acknowledge receiving support from state-funded research program of Russian Ministry of Education and Science. The results of this research were achieved within the frameworks of the governmental assignment of Russian Ministry of Education and Science in the sphere of scientific research during the researching assignment \# 26.1478.2014/K "The structural transformation of Russian Economy through the integration installation in the industrial markets of Asia-Pacific Region"
} 


\title{
ИСТРАЖИВАЊЕ ЕФЕКАТА МЕЪУКУЛТУРНИХ РАЗЛИКА НА ПОНАШАҢЕ ПОТРОШАЧА НА ТРЖИШТУ ВИСОКОГ ОБРАЗОВАЫА
}

\begin{abstract}
Апстракт
У раду се наводи да су истраживања утицаја међукултурних разлика на понашање потрошача суизазов и популарна умеђународној научној ипословној заједници и да су интердисциилинарног карактера. Циљ овог истраживања је да се развије методолошки приступ процене карактеристика међукултурног утицаја на понашање потрошача на тржишту услуга високог образовања. Модел културе који открива листу културних вредности,карактеристика материјалне и институционалне карактеристике окружена, прилагођене тржишту услуга универзитетског високог образовања, развијен је током овог истраживања. Метод за стварање случајне матриие елемената, формирање модела културе потрошача одређене земље и карактеристика понашања потрошача (студената) на тржишту услуга високог образовања груписаних према 7П комплексу ((Производ, Цена, Промоција, Људи, Прочес, Физички докази) је предложен. Развијен методолошки приступ је усвојен од стране кинеских и руских студената. Резултати истраживања могу да се користе за развијање мера за унапређење међународне конкурентности универзитета.
\end{abstract}

Кључне речи: међукултурни, модел културе, понашање потрошача

\section{Introduction}

The economic development today should be based on the improvement of the conditions for the human capital reproduction. It should occur simultaneously with the education modernization as the basic condition for a qualitative development of human resources to provide the economy proportional development. The current state of the universities necessitates the solution of a number of problems to improve their effectiveness and competitiveness.

Globalization results in boundary spanning between the countries without the cultural features sacrificing, promoting the topicality of the cross cultural investigations of the consumers' behaviour in different goods and services markets. The geographical borders are crossed with fewer risks than the cultural borders are due to the greater rigidity and resistance of the nation cultural values to any changes in comparison to the technologies and other factors affecting on the consumers' behaviour. The culture, in the current context, influences on all stages of the decision making about purchasing a good or a service by a consumer, including the problem recognition, information searching, options assessment and others. However, the consumers' choice depends on their cultural environment characteristics and on the processes of the cross-cultural interactions. The same situation is significant in the higher educational services market. Increasing competition among the countries, anticipates the necessity of searching new 
sources of the universities compatibility improvement. Consideration of the cultural characteristics of the educational service consumers' behaviour may become one of the factors for the universities international competitiveness improvement. The objective of this investigation is to develop the methodological approach and tools for investigating the cultural characteristics influence on the consumers' behaviour in the higher educational services market.

The sources of the cross-cultural scientific researches originate in the anthropologists investigations analysing the human psychology from the point of view of their scientific subjects. At present fundamental investigations in this field are conducted by scientists across the different fields of knowledge: psychology, biology, ethnopsychology, economics, management, marketing, sociology, culturology, biomedicine and others. Cross-cultural investigations in the context of the universities international competitiveness were described in some papers (Aghionet et al., 2010; Buela-Casalet et al., 2007; deFilippoet et al., 2012; Dillet et al., 2005; Filinovet et al., 2002; Glänzelet et al., 2002; Li et al., 2005; Harvey, 2008; Liuet et al., Merisotis, 2005; Merisotiset et al., 2005; Mohrman, 2013; Moket et al., 2011; Mok, 2014; Rodionovet et al., 2014; Yaşaret et al., 2012; Yonezawa et al., 2002). The cross-cultural investigations issues of customers' behaviour are described in the several papers (Agarwal et al., 2010; Al-Hyarietal et al, 2012; Cheung et al., 2011; Dimitrova et al., 2014; Gelade, 2008; Gesteland, 2012; Harrison, 2006; Hofstede et al., 2002; Redden et al., 2011; Sankaran et al., 2011; Yousaf et al., 2013).

The papers of the above mentioned scientists indicate the specificity of the culture and personality interrelations, the developed methods for studying their interrelations character, investigation of the cultural influence on the consumers' behaviour. At present the empirical approach dominates in the cross-cultural researches: most part of the theoretical conclusions is based on the field surveys. The main problem of the cross-cultural researches is the lack of the universal methodological approaches to the investigations of the cross-cultural features effect on the consumers' behaviour in different countries. The current measurement methods are the products of the certain culture, reflecting the specificity of this particular culture, which makes its adaptation difficult in the context of the other cultures. All of this proves the timeliness of the investigation topic and insufficient intensity of its study.

\section{Methodology}

The methodical tools developed for the investigation of the cross-cultural distinctions influence on the customers' behaviour on the service market starts with the determination of the investigation logics, formation of the investigation main hypothesis, development and validation of the inquiry questionnaire. The final stage is the evaluation of the suggested tools by the Chinese and Russian students.

1. Challenge problem:

The problem to be investigated is to find out the lags in the customers' behaviour in different cultures (Russian and Chinese) on the higher educational services market;

The problem to be solved is to adapt the universities marketing mix (Product, Price, Promotion, People, Process, Physical evidence) to the features of the certain culture 
consumers' behaviour while admitting and training students of different nationalities, which is the pacing factor for the international competitiveness of the university.

2. Determination of the investigation purposes and objectives:

The purpose of the investigation is to study the culture model influence on the consumers' behaviour on the higher educational services market of Russia and China.

According to this purpose the following objectives are set up in this investigation project:

a) To develop a culture model considering the higher educational services market features;

b) To determine quantitatively the culture model elements effect on the consumers' behaviour model parameters on the higher educational services market.

3. Formation of the investigation main hypothesis

Hypothesis 1: the culture model is formed under the influence of the cultural value system, institutional and material environment elements.

Hypothesis 2: consumers' behaviour features of the higher educational services market depend upon the certain country culture model.

4. The investigation methods: cabinet and field investigation using quantitative and qualitative data collection methods.

The main trends of the investigation are the following:

- $\quad$ culture values investigation (Solomon, 2012): terminal values (active exciting life, life wisdom, health, job, nature and art beauty, love, material well-being, friends, public recognition, intellectual development, productive life, physical and intellectual improvement, entertainments, freedom, family, happiness of others, art, self-confidence); instrumental values (punctuality, politeness, high-level requirements to the liveliness, sense of humor, discipline, selfconsistency, uncompromising attitude to oneself and to others, education, sense of responsibility, rationality, self-control, courage to persist in one's opinion, solid will, tolerance, honesty, understanding of the others opinion, diligence, delicacy);

- institutional environment investigation: the influence level of the global (regional) geopolitical situation on the educational institution preferences; the level of the diplomatic relations between the countries; the level of the political stability in the country; the level of the social infrastructure development, influencing on the population life quality; the level of the government educational regulations; the influence level of the country population beliefs on the educational services proposal; the influence level of the religious restrictions on the educational services consumption;

- material environment investigation: the level of the technological and scientific environmental development in the country; the education institutions availability; the level of the modern technologies and equipment utilization at the educational institutions; the education institutions geographical situation; the level of the country economic development;

- customers' behaviour features investigation on the market of the higher educational services against the 7P complex (Product, Price, Promotion, 
People, Process, Physical evidence). The issues of the marketing mix components are divided into 7 main blocks. The issues from each component were divided into sub-issues to define the respondents' relation more precisely.

Block 1. (Product):

Educational program variety:

- According to the proposed education degree (pre-higher education, bachelor, master, post-graduate);

- According to the training areas and profile;

- Joint dual-degree programs;

- Programs for professional retraining.

Block 2. (Price): cost of education.

Block 3. (Place):

- Realization of education programs by franchising;

- Existence of special agreements with the admitting higher education institutions admitting students and rendering them additional services such as the training programs for accessing a higher education institution, English language courses, training for the qualification examinations;

- The university location.

Block 4. (Promotion): promotion of the university educational programs, information about the rendered services, their quality, faculty qualification, including:

- Conducting open Information Weekends;

- $\quad$ The university site availability;

- Conducting career days;

- $\quad$ Issuing of newspapers and magazines publications, brochures.

Block 5. (People):

Academic staff, including:

- $\quad$ Average age of the academic staff;

- $\quad$ The level of the academic staff qualification;

- $\quad$ The university technical personnel.

Block 6. (Process):

- Various forms of education availability.

Block7. (Physical evidence):

The level of higher education institution social infrastructure development including:

- Dormitory availability;

- Hotel availability;

- Availability of canteens in every academic building;

- Canteen availability in every dormitory;

- Outlets for selling food products (beverages, pies, etc.) in every academic building

- $\quad$ Outlets for selling food products (beverages, pies, etc.) in every dormitory;

- Availability of the higher education institution health and recreation resort; 
- $\quad$ First-aid post availability;

- Copy shop availability;

- $\quad$ Outlets for selling stationary goods;

The development level of the material and technical facilities, providing the academic process, including:

- Stadiums availability (volleyball, football, basketball, tennis courts);

- $\quad$ Sport hall availability;

- Number of classrooms (lecture halls), specialized classrooms, laboratories;

- $\quad$ Size of classrooms (lecture halls), specialized classrooms, laboratories;

- Library availability;

- $\quad$ Free Wi-Fi availability in the academic buildings.

5. The sources of the secondary information. To develop the tools for the field investigations, content analysis of the secondary information on the studied issue should be carried out. Printed and electronic, business and specialized publications, professional books, internet resources, analytical review articles in press are recommended to be considered as the sources of the secondary information.

6. Raw information collection. The results of the Russian and Chinese student questionnaire survey are the raw information sources. The purpose of the questionnaire survey is to obtain quantitative estimates to define the dependence of the consumers' behaviour on the higher educational services market upon the culture model.

7. Determination of the sampled population. The sampled population for conducting the questionnaire survey included 520 persons. While the sampled population forming, the age, education and nationality were considered.

8. Data analysis. The obtained questionnaire survey results were processed by the statistical methods, creating the contingency matrix of the cultural elements and the consumers' behaviour parameters.

\section{Results}

The educational services market in the Asian-Pacific region is rapidly developing. Globalization and economic integration change the current education system concept. Students can choose the education level, place and ways of its obtaining. The education markets in the PRC, Singapore, Malaysia, developing at a quick rate, have already deprived the USA, Great Britain and Australian traditional markets of their competitive advantage. Today education is notably crossing over the economic life of the society and the education activity is becoming the most important component of the country economic development. Some definite trends have developed on the educational services market in the Asian-Pacific region:

- Absolute increase of the students number;

- Global education internationalization and openness (educational service export has become one of the most perspective trends of the foreign economic relations in the Asian-Pacific region countries for the last decades; 
- Higher education mass nature increase (in the XXI century higher education becomes a key and fundamental component of the human community sustainable development;

- Rush development of the East Asia countries in the field of education;

- Growth of the informational transformation (the creation of the global information networks practically effaced the boundaries between the states in the field of the educational information flow, confronted the education with an accomplished fact when not only educational institutions but also global information resources have become the source for a new knowledge and educational information obtaining);

- Continuous education;

- Increasing role of the English language in the education system;

- Higher education diversification and internationalization (diversification relates to the establishment of new educational institutions, introduction of new education trends, new disciplines, arranging interdisciplinary programs. Internationalization is aimed at the national systems rapprochement, defining and developing common universal concepts and components in them, those foundations which are the basis for the national cultures variety, contributing to their mutual enrichment and stimulating them for achieving high standards).

Educational services, having a number of unique properties relating to the consumer involvement in the production process, perishability, and intangibility of the obtained information and its quality, create some complexity problems in promoting and introducing them to the service market. Those difficulties are faced not only by the service producers, but also by the consumers who should choose the proper educational institution and education program necessary to satisfy their requirements for obtaining knowledge and appropriate education. Due to this fact, educational institutions should research the educational market, cross-cultural features of these services consumers to stay competitive.

\section{Culture model building.}

J. Moven (1995) culture matrix, adjusted to the higher educational services market was used while developing the culture model. The elements, making up the culture model, were represented as the cultural environment (terminal and instrumental values) material and institutional environment. The culture elements were evaluated by the respondents according to the Likert scale, where 1 means strongly disagree; 2 means disagree; 3 means neither agree, nor disagree; 4 means agree; 5 means strongly agree. A questionnaire survey of Chinese and Russian students was conducted on the basis of the developed methodical instruments. Its results allowed determining the significance of terminal and instrumental values for the respondents (fig. 1,2). Terminal values are the values which cannot be explained by other, more common or more important values. Such values usually include: love, happiness, wisdom and others. Personal traits backing up a person in the life are usually considered as instrumental values. They are: politeness, responsiveness, diligence and others (Solomon, 2012). 


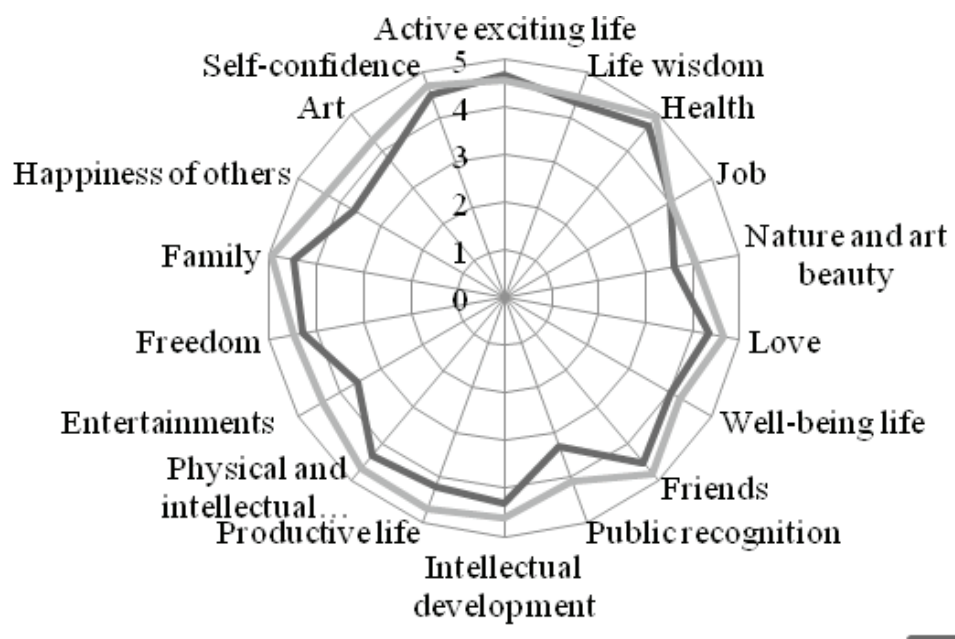

Russian students

Chinese students

Figure 1. The distribution of the respondent average estimates against the terminal values according to the Likert scale, author's development

Russian students indicated health, active life, family and self-confidence as the most important terminal values. Chinese students indicated family, health, friends, productive life, and self-confidence. The analysis outcomes showed that the most notable gaps in the terminal values significance were in such values as entertainments, public recognition. It should be noted that the investigated group (students) age peculiarities made the impact on the value system to a greater extent than the cultural features did.

Instrumental value characteristics are shown in figure 2.

\section{$\longrightarrow$ Russian students $\longrightarrow$ Chinese students}



Figure 2. The distribution of the respondent average estimates against the instrumental values according to the Likert scale, author's development 
The same sort of situation occurs while assessing the instrumental values by the Russian and Chinese students. The most important instrumental values for the Russian students are the following: independence, honesty, diligence and ability to understand someone else's point of view. Chinese students indicate the following instrumental values as the most important ones: politeness, diligence, punctuality, honesty and responsiveness. The most notable gaps in the instrumental values assessment are in such items as uncompromising attitude to disadvantages and punctuality.

The satisfaction with the elements of the material environment is characterized by the greater gaps than that with the cultural values according to the assessments of the Russian and Chinese students (Figure 3).

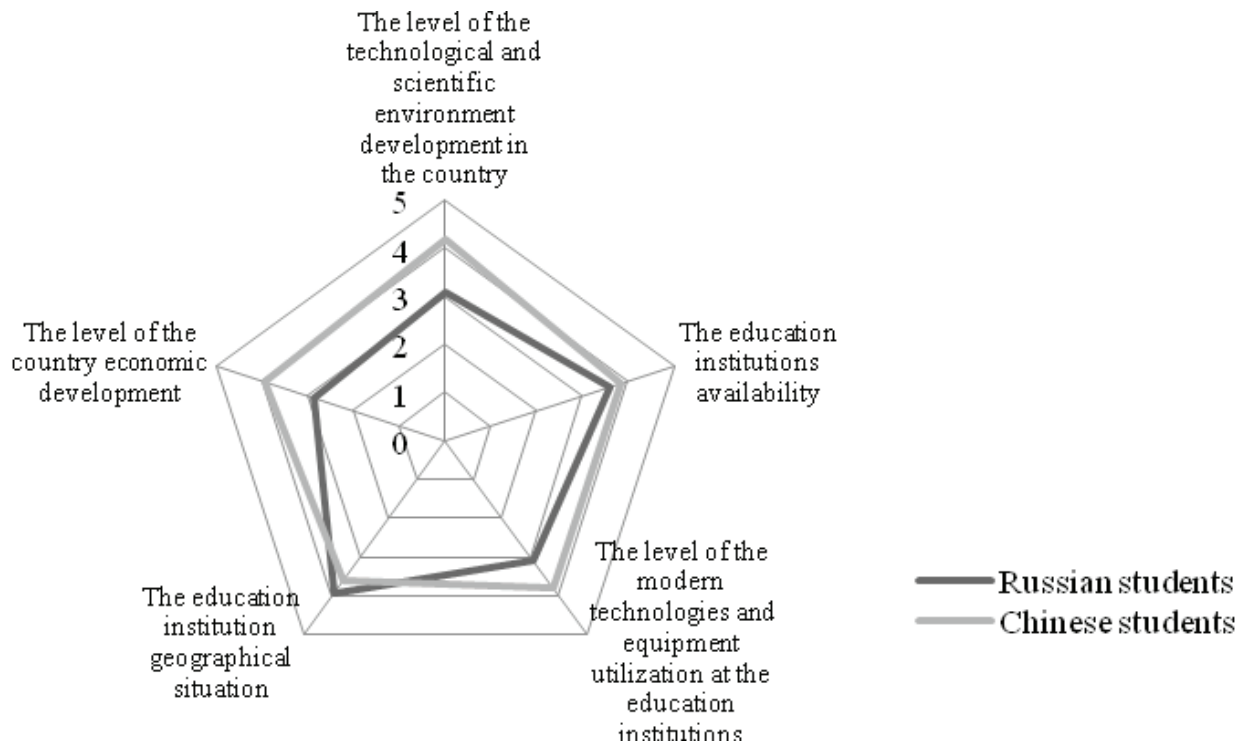

Figure 3. The distribution of the respondent average estimates against the satisfaction with the material environment characteristics according to the Likert scale, author's development

It should be noted that the Russian student satisfaction with the elements of the material environment is significantly less than that of the Chinese students, which influences on the culture model formation, that, in its turn, forms the consumers' behaviour in the higher educational services market.

The respondents' estimates of the institutional environment show that Chinese students are greatly satisfied with the institutional environment elements. The greatest gaps in the respondents' answers are stated on such indicators as the population life level and quality, the level of the political stability in the country, as well as the level of diplomatic relations between the countries. Students estimate coincide on such indicator as global (regional) geopolitical situation influence on the choice of the educational institution, which is especially important for choosing the educational institution abroad. 

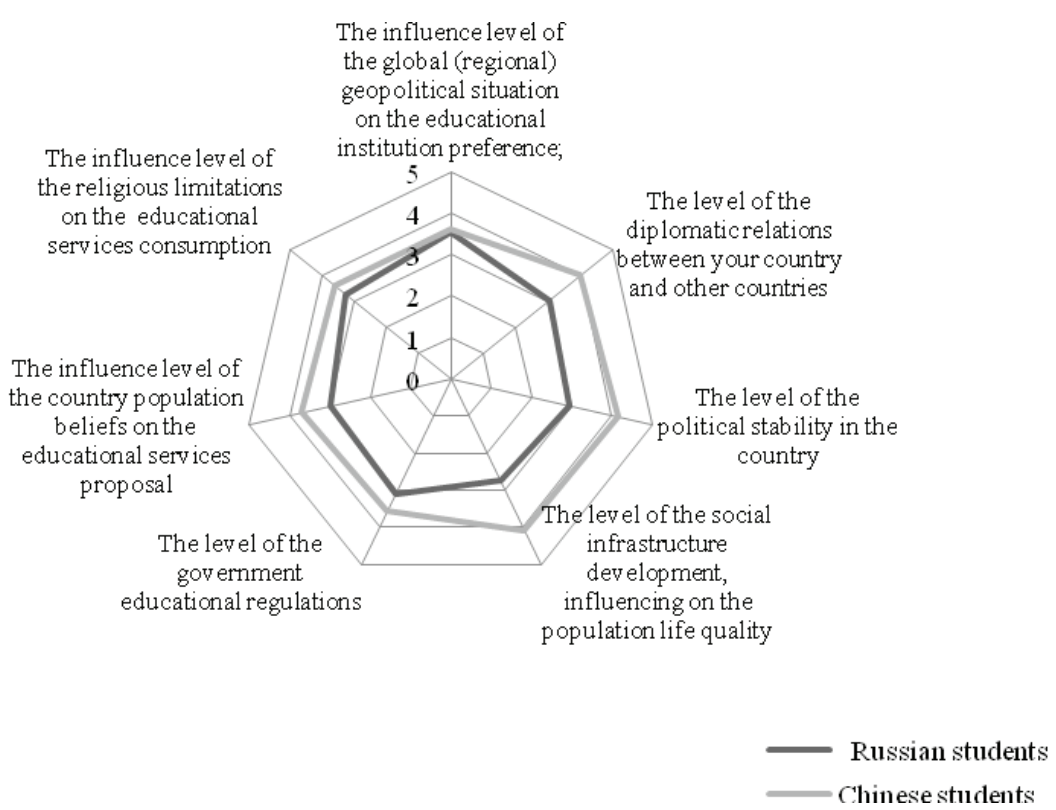

Figure 4. The distribution of the respondent average estimates against the satisfaction with the institutional environment characteristics according to the Likert scale, author's development

The hypothesis that the cultural model is formed under the influence of the cultural value system, institutional and material environment has proved to be completely true.

To confirm the second hypothesis the authors, basing on the questionnaire survey, applied the statistical analysis method by developing the contingency matrix of the elements, forming the culture model and the students' behaviour characteristics in the higher educational service market, grouped against the marketing mix 7P (Product, Price, Promotion, People, Process, Physical evidence) (table 1, 2).

Table 1. Matrix of Russian students behaviour characteristics (against Product, Price, Promotion, People, Process, Physical evidence) compliance with the culture model elements in the higher educational service market, authors development

\begin{tabular}{|l|c|c|c|}
\hline $\begin{array}{c}\text { Culture elements } \\
\text { Marketing mix elements }\end{array}$ & Cultural values & $\begin{array}{c}\text { An institutional } \\
\text { environment }\end{array}$ & $\begin{array}{c}\text { Material } \\
\text { environment }\end{array}$ \\
\hline Product & 4.3 & 4.1 & 4.3 \\
\hline Price & 4.2 & 4.3 & 3.8 \\
\hline Place & 4.2 & 4.1 & 4.2 \\
\hline Promotion & 4.8 & 4.1 & 4.3 \\
\hline People & 4.1 & 3.9 & 4.1 \\
\hline Process & 4.7 & 3.9 & 4.1 \\
\hline Physical evidence & 4.4 & 4.2 & 4.4 \\
\hline
\end{tabular}


The analysis of the contingency matrix of Russian students behaviour characteristics and the culture model elements in the higher educational service market demonstrates a high level of the culture elements influence on the consumers' behaviour in the higher educational service market (values of the marketing mix elements indicators compliance with the culture model elements vary in the range of 3.8-4.8 on the five-point scale). However, the extent of the culture model elements influences on the consumer behaviour regarding the product choice (educational service), its cost, promotion etc. is different.

Summarizing the investigation results it was found that the culture model influence on the choice of the educational level (pre-higher education, bachelor, master, post-graduate programs), major and profile, joint double degree programs, professional retraining programs were demonstrated up to an average extent (values of the marketing mix elements indicators compliance with the culture model elements vary in the range of 4.1-4.3 on the five-point scale). The same principles were found while analysing the culture model influence on the Russian students' attitude to the choice of the education costs, availability of the educational franchising programs, special agreements with the admitting high school, university location, availability of the university social infrastructure, including dormitories, hotels, canteens, food products sales outlets, university first-aid posts, copy centres etc. It should be noted that the culture model elements have special effect on the students' preferences in choosing the communication options (open Information Weekends, university site, career days, newspaper and magazine publications, advertising materials etc.) which affect cultural values to a greater extent ( 4.8 points to 5$)$

The culture model influence on the Chinese students' behaviour in the higher educational service market is slightly different (Table 2).

Table 2. Matrix of Chinese student behaviour characteristics (against Product, Price, Promotion, People, Process, Physical evidence) compliance with the culture model elements in the higher educational service market, authors development

\begin{tabular}{|l|c|c|c|}
\hline $\begin{array}{c}\text { Culture elements } \\
\text { Marketing mix element }\end{array}$ & Cultural values & $\begin{array}{c}\text { An institutional } \\
\text { environment }\end{array}$ & $\begin{array}{c}\text { Material } \\
\text { environment }\end{array}$ \\
\hline Product & 4.4 & 4.5 & 4.1 \\
\hline Price & 4.6 & 4.7 & 5.0 \\
\hline Place & 4.5 & 4.6 & 4.9 \\
\hline Promotion & 4.5 & 4.5 & 4.9 \\
\hline People & 4.3 & 4.4 & 4.7 \\
\hline Process & 4.4 & 4.5 & 4.8 \\
\hline Physical evidence & 4.4 & 4.5 & 4.9 \\
\hline
\end{tabular}

The high level of the institutional and material environment, development interrelations and their influence on the consumers' behaviour in the higher educational service market can be traced when the educational program, its cost, students' requirements for the academic process arrangement and for the university social infrastructure conditions are chosen. The institutional and material environments, in their turn, influence on the cultural values formation for the certain nation representatives. 
The culture model is more influential on the Chinese students' preferences in the cost, university location and on their respond to the certain promotional tools.

\section{Conclusion}

The outcomes of the investigation are the following:

1. The methodological approach and the tools for analysing cross-cultural distinctions effect on the students' attitude to the offered higher education services in terms of 7P (Product, Price, Promotion, People, Process, Physical evidence) were developed.

2. The following factors effecting the culture models formation and building were determined:

- The list of cultural values (terminal and instrumental);

- Institutional environment elements (the influence level of the global (regional) geopolitical situation on the educational institution preference; the level of the diplomatic relations between the countries; the level of the political stability in the country; the level of the social infrastructure development, providing the population life quality; the level of the government education regulations; the influence level of the country population beliefs on the educational services proposal; the influence level of the religious restrictions on the educational services consumption;

- Material environment elements: (the level of the technological and scientific environmental development in the country; the education institutions availability; the level of the modern technologies and equipment utilization at the education institutions; the education institutions geographical situation; the level of the country economic development).

The culture models for the analysed countries adapted to the certain Asia-Pacific region countries educational services markets were built on the basis of the determined factors. The gaps between the Russian and Chinese culture models were defined during the cross-cultural analysis. The factor analysis influencing on the culture model formation confirmed the hypothesis that the cultural value system, institutional and material environment elements were the most significant factors.

3. The methodological approach and the tools for estimating the culture elements influence on the students' attitude to the choice of the educational services offered by the universities in terms of 7P (Product, Price, Promotion, People, Process, Physical evidence) was suggested. The cross-cultural gaps between the Russian and Chinese students' behaviour on the higher educational services market, which should be considered by the universities to improve their international compatibility, were determined on this basis. The high level of the cultural values influence on the students respond to different promotion complexes elements used by the universities was specified. Unlike Russian students, the Chinese students cultural features are to the great extent formed under the influence of the institutional and material environment elements, which in their turn, influence on their cultural value system changes. 
Future investigations of these issues can be aimed at the confirmation of the hypotheses suggested in the paper on the extended empirical investigations by the example of the increased number of both Asian and European countries. A complex approach, including both quantitative and qualitative investigation methods (focusgroups, in-depth interviews with the representatives of different cultures of the target group and others) is needed.

\section{Reference}

Agarwal, J., Malhotra Naresh, K., \& Bolton, Ruth N. (2010). A Cross-National and Cross-Cultural Approach to Global Market Segmentation: An Application Using Consumers' Perceived Service Quality. Journal of International Marketing, 18(3), 18-40.

Aghion, P., Dewatripoint, M., Hoxby, C.M., Mas-Colell, A. \& Sapir A. (2010). The governance and performance of research universities: Evidence from Europe and the USA. Economic Policy, 25(61), 7-59.

Al-Hyari, K., Alnsour, M., Al-Weshah, G., \& Haffar, M. (2012). Religious beliefs and consumer behaviour: From loyalty to boycotts. Journal of Islamic Marketing, 3(2), 155-174.

Buela-Casal, G., O. Gutiérrez-Martínez, M. Bermúdez-Sánchez \& Vadillo-Muñoz O. (2007). Comparative study of international academic rankings of universities. Scientometrics, 71(3), 349-365

Cheung, F.M., Van de Vijver, F. J. R., \& Leong, F. T. L. (2011). Toward a new approach to the assessment of personality in culture. American Psychologist, 66(7), 593603.

de Filippo, D., Casani, F., García-Zorita, C., Efraín-García, P. \& Sanz-Casado, E. (2012). Visibility in international rankings. Strategies for enhancing the competitiveness of Spanish universities. Scientometrics, 93(3), 949-966.

Dill, D. D., Soo, M. (2005). Academic quality, league tables and public policy: A cross-national analysis of university ranking systems. Higher Education, 49, 495-533.

Dimitrova, R., Bender, M. \&Van de Vijver, F. J. R. (2014). Global perspectives on well-being in immigrant families. New York, NY: Springer, 291-310.

Filinov, N. B. Ruchkina, S. (2002). The ranking of higher education institutions in Russia: some methodological problems, Higher Education in Europe, 27, 407421.

Gelade, G. A. (2008). IQ, cultural values, and the technological achievement of nations. Intelligence, 36(6), 711-718.

Gesteland, Richard R. (2012). Cross Cultural Business Behaviour: Negotiating, Selling, Sourcing and Managing Across Cultures. Copenhagen Business School Press. 
Glänzel, W., De Lange, C. (2002). A distributional approach to multinationality measures of international scientific collaboration, Scientometrics, 54, 75-89.

Harrison, L. E. (2006). The Central Liberal Truth: How Politics Can Change a Culture and Save It from Itself. Oxford University Press.

Harvey, L. (2008). Rankings of higher education institutions: A critical review Quality in Higher Education, 14(3), 187-207.

Hofstede, G.J., Pedersen, P.B. \& Hofstede, G. (2002). Exploring Culture: Exercises, Stories and Synthetic Cultures. Yarmouth, Maine: Intercultural Press.

Li, M., Shankar, S. \& Tang, K.K. (2011). Why does the USA dominate university league tables? Studies in Higher Education. 36(8), 923-937

Liu, N. C., Cheng, Y. (2005). The academic ranking of world universities, Higher Education in Europe, 30, 127-136.

Merisotis, J. P. (2005). On the ranking of higher education institutions, Higher Education in Europe, 30, 361-363.

Merisotis, J. P., Sadlak, J. (2005). Higher education rankings: Evolution, acceptance, and dialogue, Higher Education in Europe, 30, 97-101.

Mohrman, K. (2013). Are Chinese universities globally competitive?. China Quarterly, 215, 727-734.

Mok, K.H. (2014). Enhancing quality of higher education for world-class status: Approaches, strategies, and challenges for Hong Kong. Chinese Education and Society, 47(1), 44-64

Solomon, M. (2012). Consumer Behaviour. Prentice Hall of India.

Moven, J. (1995). Consumer Behaviour. 4th ed. Macmillan Publishing Co. 